\title{
Identification of $\mathrm{Cu}$ in Crassostrea virginica Tissue Using the Technique of Laser-Induced Breakdown Spectroscopy (LIBS)
}

\author{
Xochitl Patricia Urrutia-Meza, Fabio Felipe Chalé-Lara, Rogelio Ortega-Izaguirre \\ Instituto Politécnico Nacional, Centro de Investigación en Ciencia Aplicada y Tecnología Avanzada U. Altamira, \\ Altamira, México \\ Email: rortegai@ipn.mx
}

How to cite this paper: Urrutia-Meza, X.P., Chalé-Lara, F.F. and Ortega-Izaguirre, R. (2021) Identification of $\mathrm{Cu}$ in Crassostrea virginica Tissue Using the Technique of Laser-Induced Breakdown Spectroscopy (LIBS). Optics and Photonics Journal, 11, 51-62.

https://doi.org/10.4236/opj.2021.113004

Received: February 11, 2021

Accepted: March 19, 2021

Published: March 22, 2021

Copyright (c) 2021 by author(s) and Scientific Research Publishing Inc. This work is licensed under the Creative Commons Attribution International License (CC BY 4.0).

http://creativecommons.org/licenses/by/4.0/

\begin{abstract}
The analysis of metals in aquatic organisms is of great importance due to the health problems they can cause to be consumed by human beings. In this study, the Laser-Induced Plasma Spectroscopy (LIBS) technique is evaluated as an alternative method to identify $\mathrm{Cu}$ in Crassostrea virginica oysters' tissue. It focuses on the characterization of oysters caught a natural bank and the identification of different $\mathrm{Cu}$ concentrations. To carry out experimentation, oyster samples were collected in autumn (October 2017) and spring (May 2018) from San Andres Lagoon, Aldama, Tamaulipas. A single pulse Nd:YAG laser (1064 nm) was used, and tissue was contaminated with $0,2,10$, 20, 50, and $100 \mu \mathrm{g} / \mathrm{g}$ of $\mathrm{Cu}$. In tissue were identified atomic lines for $\mathrm{Ca}, \mathrm{Cr}$, $\mathrm{Mg}, \mathrm{Mn}, \mathrm{Na}, \mathrm{N}, \mathrm{O}$, and $\mathrm{H}$. However, the intensities of emission lines for autumn samples were greater than spring samples. $\mathrm{Cu}$ emission lines at 324.6, $327.1,510.3,515.1$, and $521.5 \mathrm{~nm}$ were found for contaminated pills. The intensity of emission lines showed a linear increase with the concentration; whereby, they can be used as calibration curves to quantify $\mathrm{Cu}$ concentrations in oyster tissue.
\end{abstract}

\section{Keywords}

LIBS, Crassostrea virginica, Heavy Metals

\section{Introduction}

Chemical pollutants negatively impact aquatic ecosystems; it is common to find human diseases such as digestive disorders and poisonings derived from consuming products contaminated by heavy metals [1]. Therefore, it is essential to identify and evaluate the concentration of heavy metals in aquatic organisms pe- 
riodically. Among the organisms most vulnerable to aquatic contamination are mollusks [2]. They are sessile and filtering organisms exposed to the accumulation of heavy metals, promoting the biomagnification that affects human beings. An aquatic ecosystem can be characterized through the analysis of heavy metals in mollusks tissue. Oysters are indicators of bioaccumulation due they are sessile organisms and their location in the trophic chain [3]. On the other end, consuming oysters provides an essential source of nutrients [4].

A variety of techniques such as atomic absorption spectroscopy (AAS) [5] [6] [7], wavelength dispersive X-ray fluorescence (WDXRF) [8], and inductively coupled plasma mass spectrometry (ICP-MS) [9] [10] [11] are commonly used to analyze oyster tissue. However, many of these techniques are not readily translatable into field instruments [12] due to prolonged and complicated sample preparation steps that produce chemical residues. Thus, classical techniques are far from low cost and being implemented in real-time [13].

The laser-induced breakdown spectroscopy (LIBS) is an atomic emission spectroscopy technique capable of determining any material's elemental composition in real-time. Focusing the energy of a laser pulse on the sample surface produces plasma that gives information about the material composition [14]. Spectral features such as emission lines, peak intensity, and integrated intensity determine the elemental concentration of the target or discriminate one material from another through their unique spectral signatures [15]. This technique has the advantages of not needing sample preparation; likewise, it could analyze samples in any state of matter. Also, LIBS analysis is relatively fast since, with a laser shot (20 ns), it is possible to obtain the sample's emission spectrum [16].

LIBS has proved to be a powerful technique for elemental analysis of shells [17] and mollusk tissue [12], and the identification of metals in fresh fish [5]-[18]. However, there are no recent studies about the content of cooper in $C$. virginica organisms from San Andres lagoon; this may be due to the complexity of transportation, processing, and materials necessary to analyze heavy metals. In this paper, the natural Crassostrea virginica tissue and cooper contaminated tissue are analyzed with the Laser-Induced Breakdown Spectroscopy technique.

\section{Study Area}

Figure 1 shows the sampling site, which corresponds to a natural oyster bank, located at $22^{\circ} 42^{\prime} 50.82^{\prime \prime} \mathrm{N}$ and $97^{\circ} 51^{\prime} 44.79^{\prime \prime} \mathrm{W}$ at the mouth of the Rio Tigre near the San Andres Lagoon, Aldama, Tamaulipas, Mexico. San Andres Lagoon is a region of fishing and shrimp farms located on the western Gulf of México in the Tamaulipas State $\left(22^{\circ} 32^{\prime} \mathrm{N}-22^{\circ} 47^{\prime} \mathrm{N}\right.$ and $\left.97^{\circ} 41 \mathrm{~W}-97^{\circ} 54^{\prime} \mathrm{W}\right)$. It communicates with the Gulf of Mexico through the mouth of Chavarría and receives contributions from Tiger and Barberena rivers. The lagoon is a nursery and growing zone; its biodiversity includes mollusks, crustaceans, fish, turtles, birds, seagrasses, and mangroves [19]. Due to its physical characteristics, it exposes changes in lagoon depth due to rain and tides. Previous research has been reported metal 


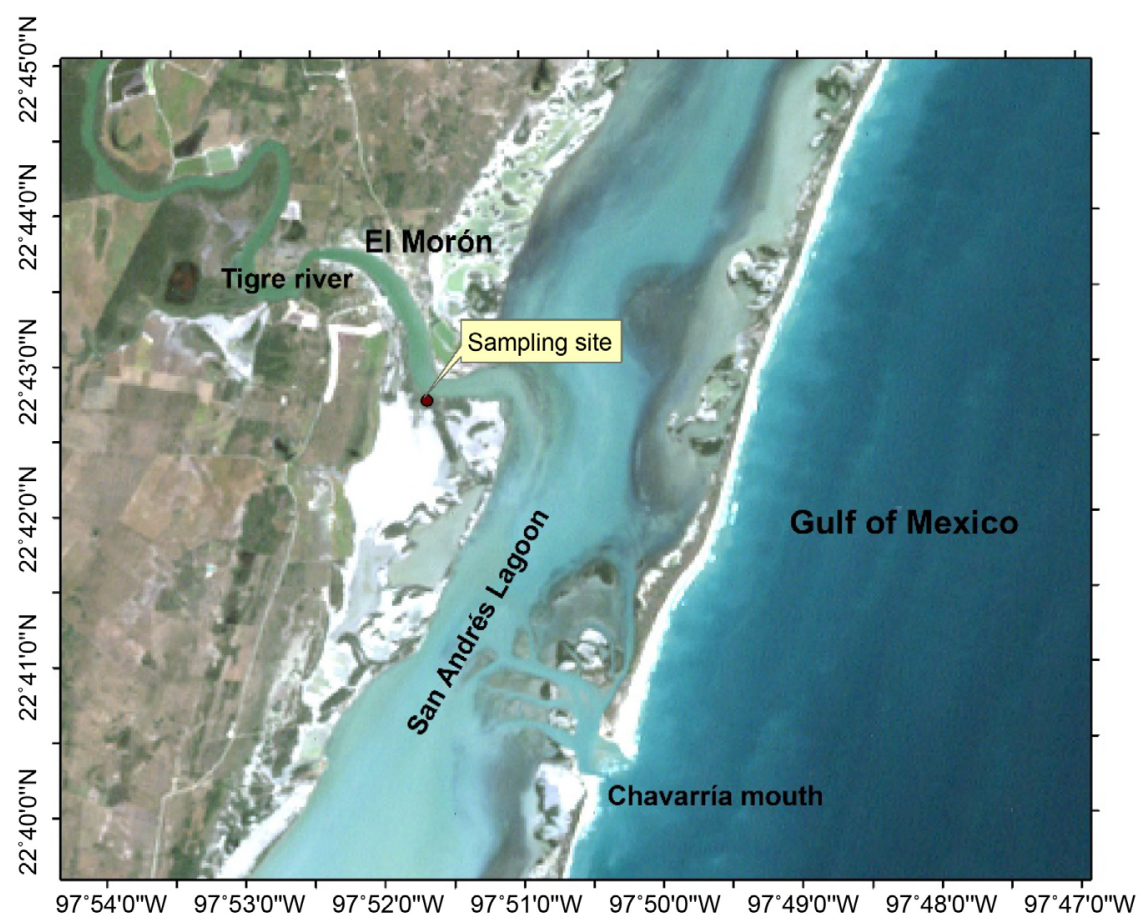

Figure 1. Sampling site in the San Andres Lagoon, Aldama, Tamaulipas, Mexico.

concentrations in water, sediment, and $C$. virginica oyster tissue [20]. The commercial fishery of Crassostrea virginica oysters is a highly relevant productive activity in Southern Tamaulipas.

\section{Experimental Details}

Figure 2 shows the LIBS experimental setup employed in all the experiments described in this work. The samples were ablated with an Nd-YAG laser (Quantel Q-smart 450), delivering $200 \mathrm{~mJ} /$ pulse at a wavelength of $1064 \mathrm{~nm}$ with a pulse duration of $10 \mathrm{~ns}$ FWHM and rate repetition of $4 \mathrm{~Hz}$. The light emitted by the plasma was collected using an optical fiber (with diameter $200 \mu \mathrm{m}$ ) connected to an Ocean Optics Spectrometer USB4000 with a spectral range of 200 $900 \mathrm{~nm}$. Besides, the installation includes a delay device and photodetector that allows delaying the spectrum's time of capture. The spectrometer's capture time is microseconds after the laser trigger occurring; the delay time used was $2 \mathrm{~ms}$.

For the equipment calibration and to find the lines associated with the Copper element, 50 spectra were taken from a Copper standard with $99.99 \%$ purity of the Kurt J. Lesker brand. Figure 3 shows the highest intensity peaks in the 300 to $550 \mathrm{~nm}$ range. For the identification of the average rise of each line, a Gaussian function was fitted, and $\mathrm{Cu}$ I peaks were located at 324.6, 327.1, 510.3, 515.1, and $521.5 \mathrm{~nm}$, which coincide with the NIST database [21].

\section{Sample Preparation}

C. virginica organisms were collected in October 2017 and May 2018. Thirty 


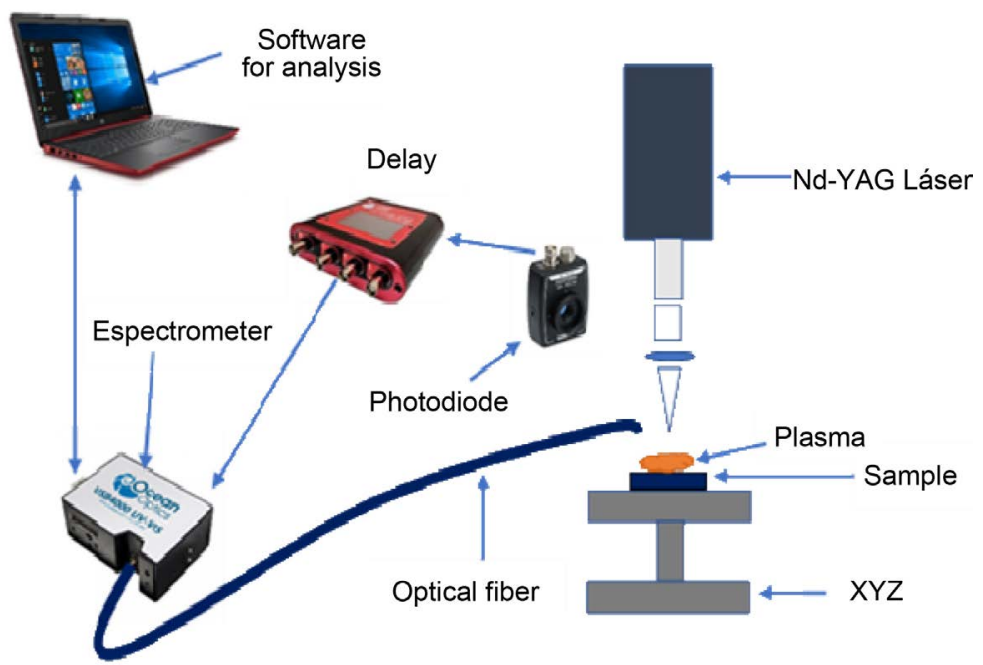

Figure 2. LIBS experimental setup.

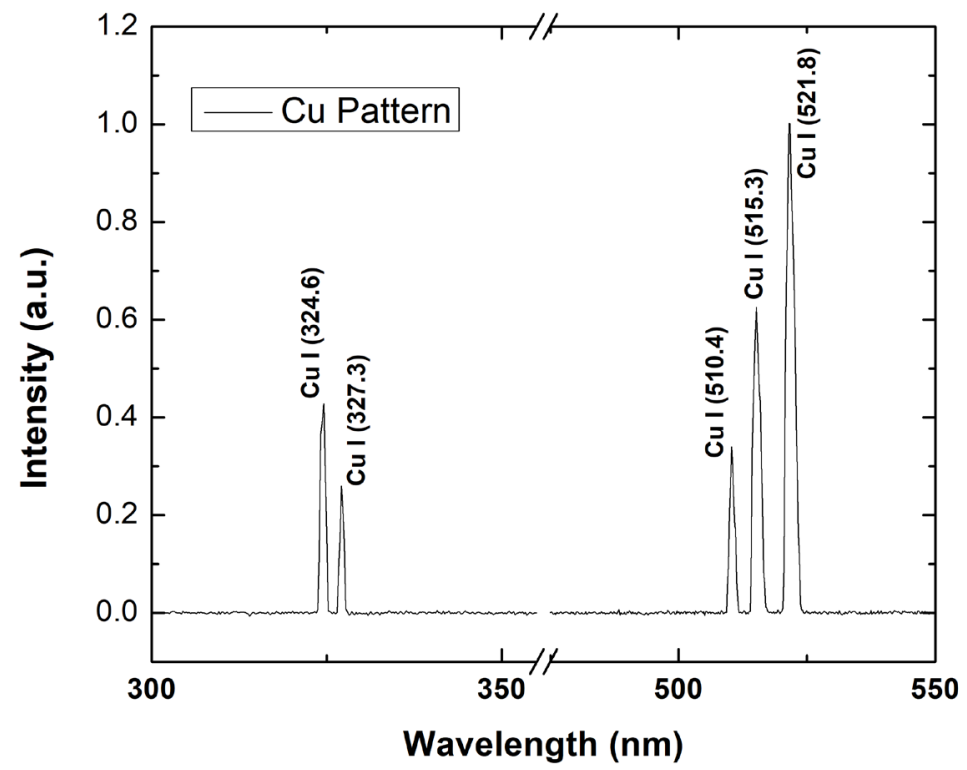

Figure 3. LIBS spectrum of Cu pattern.

oysters of different sizes were manually caught at $0.5 \mathrm{~m}$ depth in the river substrate for each sampling. Each specimen was washed with distilled water, removing the remains of sediment, epibionts, and predators. The weight of each organism was determined with an electronic balance (precision $0.1 \mathrm{~g}$ ), and measures of length, width, and thickness were obtained with a digital vernier (Mitutoyo). The condition index (CI) was calculated according to the method proposed in [22]. The tissues and shells of 30 specimens were used, soft tissues were dried and dry weight was then determined. The $\mathrm{CI}$ was calculated as: $\mathrm{CI}=$ $(\mathrm{W} 1 \times 1000) / \mathrm{W} 2$, where W1 is the dry weight of soft tissue $(\mathrm{g})$ and W2 is the dry weight of the shell $(\mathrm{g})$. The index reflects the oyster's physiological condition; that is, it allows determining how environmental parameters affect growth and its gametogenic activity. 
Oysters were chipped using a spatula, and the tissue was extracted. Tissue was placed in a glass container and dried in a muffle at $70^{\circ} \mathrm{C}$ for 24 hours to remove the water content. The tissue was ground in a glass mortar and sieved with a $0.0029 "$ mesh (\#200). Two pills $\left(\mathrm{P}_{\text {May }}, \mathrm{P}_{\text {Oct }}\right)$ of 1 g., $18 \mathrm{~mm}$ diameter and $3 \mathrm{~mm}$ thickness were obtained with the sieved tissue pressed to 10 tons for 2 minutes with a hydraulic press (Hydra).

Fifty laser shots were applied to each pellet to obtain LIBS spectra of samples. The spectrometer software averaged the resulting 50 spectra, bringing the average spectrum. Each spectrum's Emission lines were fitted to a Gaussian function, and the peaks were compared with the NIST database.

To identify the concentration at which $\mathrm{Cu}$ is detected using the LIBS technique, the tissue of $C$. virginica was contaminated with Cupric Nitrate $\mathrm{Cu}\left(\mathrm{NO}_{3}\right)_{2}$ from Baker Analyzed A. C. S. Reagent Pm 232.590S. This analysis was performed with oysters captured in May 2018. Five work standards were performed corresponding to concentrations $2,10,20,50$, and $100 \mu \mathrm{g} / \mathrm{g}$ of $\mathrm{Cu}$. One gram of oyster tissue was contaminated with $1 \mathrm{ml}$ of each $\mathrm{Cu}$ concentration. Samples were dried ( 24 hours, $70^{\circ} \mathrm{C}$ ) and pressed (10 tons) to obtain pills $\mathrm{P}_{2}, \mathrm{P}_{10}, \mathrm{P}_{20}, \mathrm{P}_{50}$ and $\mathrm{P}_{100}$ with $2,10,20,50$ and $100 \mu \mathrm{g} / \mathrm{g}$ of $\mathrm{Cu}\left(\mathrm{NO}_{3}\right)_{2}$, respectively. In the experiments, the $\mathrm{P}_{\text {May }}$ pill was used as a blank. Fifty laser shots were applied to each contaminated pellet and the blank. To identify the emission lines, the procedure described previously was followed.

\section{Results}

For oysters captured in October 2017, the average length was $71 \pm 7 \mathrm{~mm}$, the average width was $38 \pm 4 \mathrm{~mm}$, and the thickness was $22 \pm 3 \mathrm{~mm}$. Otherwise, oysters collected in May 2018 had an average length of $68 \pm 11 \mathrm{~mm}$, the average width was $38 \pm 5 \mathrm{~mm}$, and the thickness was $26 \pm 5 \mathrm{~mm}$. These results indicate that the oysters analyzed were adults. Meanwhile, the condition index was 18.2 and 24.6 for October and May, respectively.

Figure 4 shows the LIBS spectra corresponding to the analysis of an oyster sample ablated at frequencies of $1,2,4,10$, and $20 \mathrm{~Hz}$ to obtain the spectrum's lowest background. At frequencies of 1,2 , and $4 \mathrm{~Hz}$, there is a low background, and at higher frequencies, the intensity of the background increases, and intensity saturation occurs. In LIBS experiment is common to have a noticeable continuum background, which typically occurs due to Bremsstrahlung and recombination radiation. In general, the low background is very important when spectra LIBS are used for material identification [23]. The $4 \mathrm{~Hz}$ frequency was selected due to the spectra have the lowest background and the highest emission intensities.

Figure 5 shows the characteristic LIBS spectra for pills $\mathrm{P}_{\text {May }}, \mathrm{P}_{\text {Oct }}$. The LIBS spectra are complex due to multiple elements present in the tissue of oysters. In the $\mathrm{P}_{\text {May }}$ spectrum, lines associated with $\mathrm{Ca}, \mathrm{Cr}, \mathrm{Mn}, \mathrm{N}, \mathrm{Mg}, \mathrm{Na}, \mathrm{O}$ and $\mathrm{H}$ are present. Almost all of the $\mathrm{P}_{\text {Oct }}$ spectrum lines are present in the $\mathrm{P}_{\text {May }}$ spectrum, 


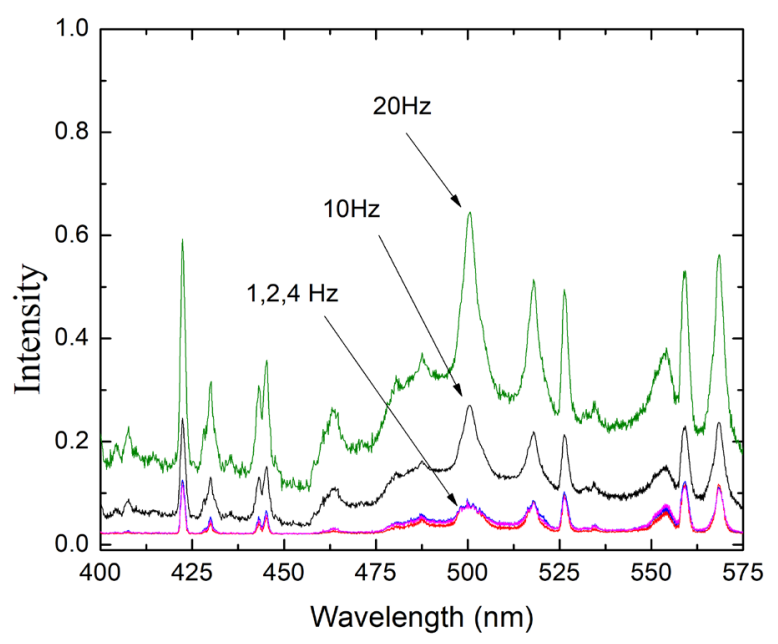

Figure 4. LIBS spectra of oyster sample irradiated with different laser frequency.

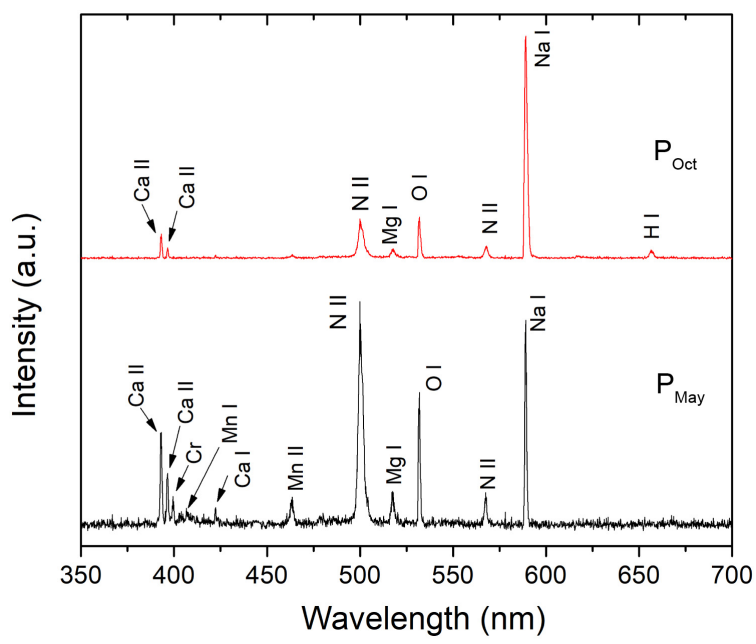

Figure 5. LIBS spectra for oyster samples $\mathrm{P}_{\text {Oct }}$ and $\mathrm{P}_{\text {May }}$.

but with lesser intensity. Such is the case of the $\mathrm{Na}$ and $\mathrm{Mg}$ lines, both elements belonging to the oyster's natural content [24] [25]. The $\mathrm{Na} / \mathrm{Mg}$ ratio was calculated to observe the relationship of intensities between samplings. For the October sampling, the rate was 0.68 , and for the May sampling, the value was 0.94 . These results show that oysters caught in May have a higher amount of Sodium than Magnesium. The list of emission lines is presented in Table 1.

Figure 6 shows a LIBS spectrum of five oyster tissue pills contaminated with $2,10,20,50$, and $100 \mu \mathrm{g} / \mathrm{g} \mathrm{Cu}$ and the uncontaminated blank. Fifty different spectra were taken from each sample, and an average spectrum was generated for each tablet analyzed. The wavelength range where the Copper lines appear is highlighted with red rectangles.

All emission lines presented in Table 1 were also found in the samples contaminated with $\mathrm{Cu}$. Also, the emission line on $531.8 \mathrm{~nm}$ (O I) was observed in the uncontaminated sample. Contaminated samples show a peak at $777 \mathrm{~nm}$ 


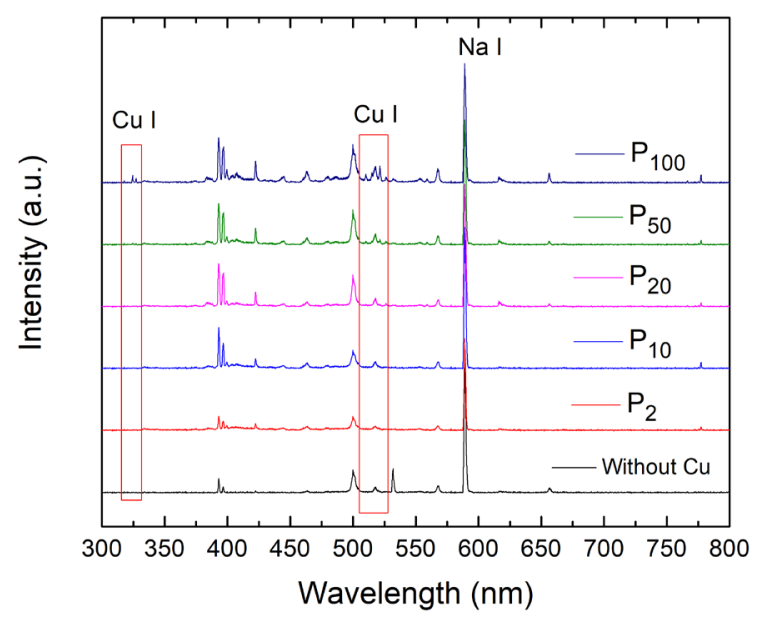

Figure 6. LIBS spectra for oyster tissue contaminated with $\mathrm{Cu}$.

Table 1. Elemental emission lines used in the spectral fingerprint of the oysters.

\begin{tabular}{ccc}
\hline Peak & Central Wavelength $(\mathrm{nm})$ & Element (NIST) \\
\hline 1 & 393.14 & Ca II (393.3) \\
2 & 396.5 & Ca II $(396.8)$ \\
3 & 399.58 & Cr I $(399.08,400.13)$ \\
4 & 407.15 & Mn I (407.9) \\
5 & 422.37 & Ca $(422.7)$ \\
6 & 463.4 & Mn II (463.9) \\
7 & 500.52 & N II (500.4) \\
8 & 517.63 & Mg I (518.42) \\
9 & 531.8 & O I (532.4) \\
10 & 567.46 & N II (567.8) \\
11 & 589.1 & Na I (589.5) \\
12 & 656.69 & H I (656.26) \\
\hline
\end{tabular}

associated with the Oxygen added through the Cupric Nitrate $\mathrm{Cu}\left(\mathrm{NO}_{3}\right)_{2}$.

Figure 7 shows the LIBS spectrum of $C$. virginica tissue contaminated with $\mathrm{Cu}$ in the region a) $320-332$ and b) $505-530 \mathrm{~nm}$. The $\mathrm{Cu}$ emission lines in the contaminated pill with $50 \mu \mathrm{g} / \mathrm{g}$ begin to be distinguished; however, the intensity of $\mathrm{Cu}$ lines for $100 \mu \mathrm{g} / \mathrm{g}$ pill is clearly distinguishable.

Figure 8 shows the intensities of $\mathrm{Cu}$ emission lines as a function of its concentration, which results from applying linear regression to data, and the correlation coefficient $(\mathrm{R})$. All $\mathrm{Cu}$ lines increase in intensity associated with copper contamination, and significant correlations greater or equal to 0.95 ( $\mathrm{p} \leq 0.05)$; however, the emission line at $521.5 \mathrm{~nm}$ has the highest correlation (0.97) concerning the regression line. 


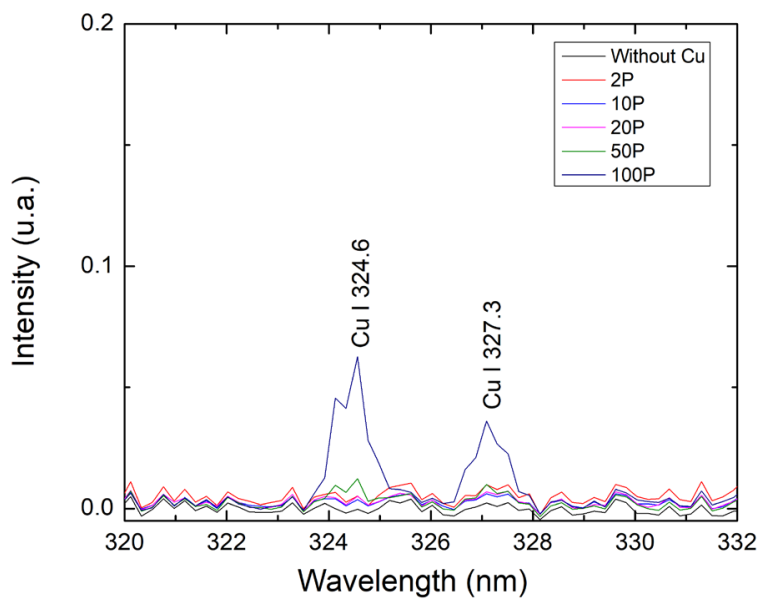

(a)

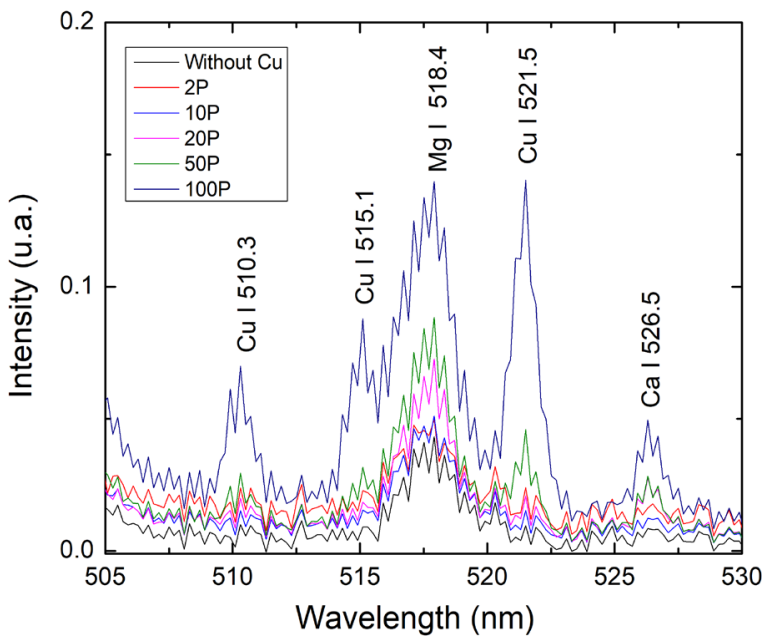

(b)

Figure 7. LIBS spectrum region (a) $320-332 \mathrm{~nm}$, and (b) 505 - $530 \mathrm{~nm}$ of $C$. virginica pills contaminated with $\mathrm{Cu}$.

\section{Discussion}

Organisms caught during spring (May 2018) had an average length of $68 \pm 11$ $\mathrm{mm}$. In autumn (October 2017), the average length was $71 \pm 7 \mathrm{~mm}$. These results indicate that the organisms were commercial-sized adults who reproduced at least once [26]. On the other end, the condition index is essential to evaluate the nutritional status of bivalves and their commercial quality and determine different contaminants or diseases. The gametogenic cycle or food availability may explain the low physiological condition index [27].

In our study, emission lines for $\mathrm{Ca}, \mathrm{Cr}, \mathrm{Mn}, \mathrm{N}, \mathrm{Mg}, \mathrm{Na}$, and $\mathrm{H}$ were identified in oyster pellets analyzed. These partially agreed with the lines presented in [12]. They collected $C$. virginica organisms at six sample sites from two coastal estuarine reserves: 4 locations in Grand Bay, Mississippi in March 2011, and 2 points in Apalachicola Bay, Florida, in February of the same year. Using LIBS spectral analysis, they identified the lines of $\mathrm{Al}, \mathrm{C}, \mathrm{Ca}, \mathrm{H}, \mathrm{K}, \mathrm{Mg}, \mathrm{Na}, \mathrm{Si}, \mathrm{Sr}$, and $\mathrm{Zn}$ and 


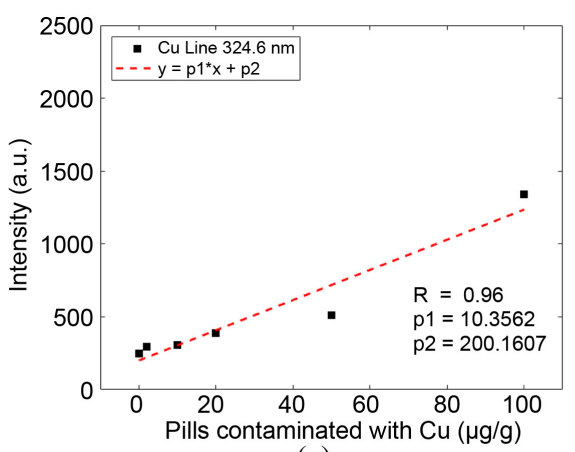

(a)

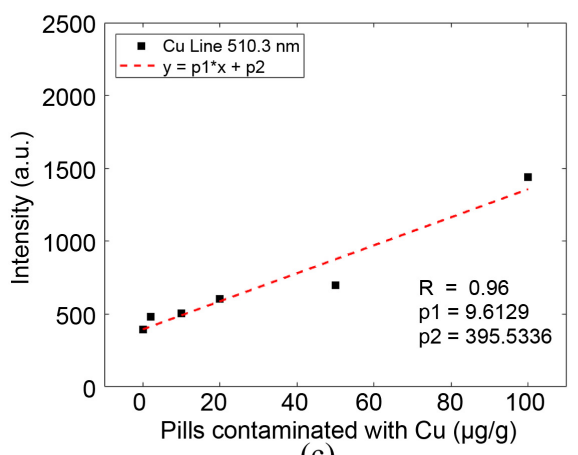

(c)

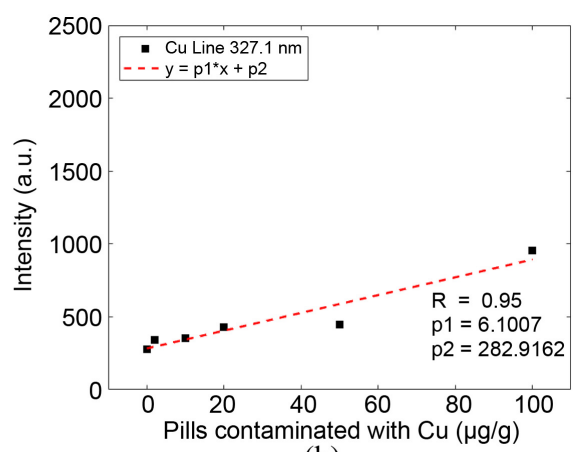

(b)

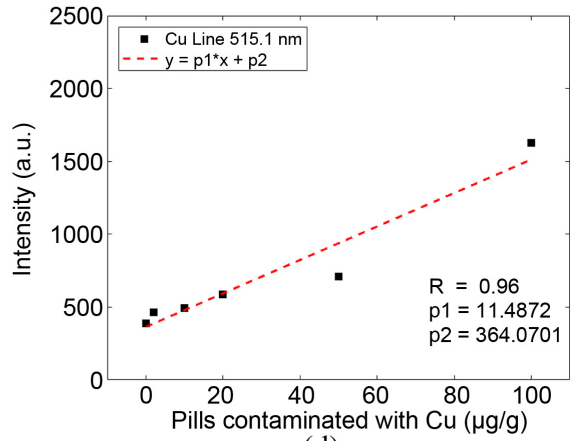

(d)

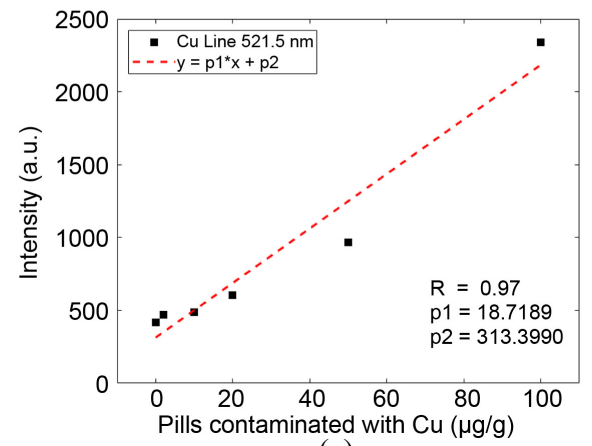

(e)

Figure 8. Intensities of $\mathrm{Cu}$ emission lines: (a) $324.6 \mathrm{~nm}$, (b) $327.1 \mathrm{~nm}$, (c) $510.3 \mathrm{~nm}$, (d) $515.1 \mathrm{~nm}$, and (e) $521.5 \mathrm{~nm}$; for concentrations $0,2,10,20,50$, and $100 \mu \mathrm{g} / \mathrm{g}$.

made intra-site and inter-site clusters of the oysters according to their geographical origin. Furthermore, our samples also showed lines associated with $\mathrm{Cr}$ and Mn. From the nutritional point of view [28], traces of the major essential nutrients $\mathrm{Ca}, \mathrm{Na}$, and $\mathrm{Mg}$, and ultra-essential nutrients such as $\mathrm{Cr}$ and $\mathrm{Mn}$ are present in the oysters' tissue analyzed in this research.

Based on the NIST database, Al I has emission lines at 394.4 and $396.2 \mathrm{~nm}$, very close to those of Ca II $(396.3 \mathrm{~nm}, 396.8 \mathrm{~nm})$; however, they vary in intensity is likely no aluminum present in our samples. Our spectra do not contain emission lines lesser than $380 \mathrm{~nm}$ due to the spectrometer technical characteristics, so it was impossible to identify $\mathrm{C}, \mathrm{Si}$, and $\mathrm{Zn}$.

The emission line at $521.5 \mathrm{~nm}$ presented the highest intensity when increasing the $\mathrm{Cu}$ concentration. Furthermore, when applying the least-squares method, a correlation coefficient of 0.97 was found. These results open the possibility of 
using the method proposed in [18] to quantify $\mathrm{Cu}$ concentrations utilizing LIBS. Our results agree with [18] in which the $\mathrm{Cu}$ emission lines show an increase when the $\mathrm{Cu}$ concentration is greater than or equal to $100 \mu \mathrm{g} / \mathrm{g}$.

\section{Conclusions}

Our results show that through LIBS technique can identify $\mathrm{Cu}$ concentrations in oyster tissue. The intensity of emission lines $324.6,327.1,510.3,515.1$, and 521.5 $\mathrm{nm}$ present a linear behavior associated with the $\mathrm{Cu}$ concentration. We consider it convenient to repeat the experiment with a higher number of $\mathrm{Cu}$ concentrations to improve the linear fit. On the other hand, identifying the detection limit continues to be an open problem, for which it would be desirable to explore the capacity of the technique to identify $\mathrm{Cu}$ concentrations lower than $50 \mu \mathrm{g} / \mathrm{g}$. Also, it is necessary to determine the calibration curve to estimate $\mathrm{Cu}$ concentration, and results must be validated using techniques such as ICP or atomic absorption.

The oyster Crassostrea virginica is a natural resource of economic importance in the study area, so its characterization is relevant. Hence, the LIBS technique can carry out continuous monitoring of natural banks or oyster crops at different times of the year. Our results show that the applied method can identify seasonal differences; however, the causes were not determined. The methodology applied to tissue samples can be used to analyze other aquatic organisms (mollusks, crustaceans, fish, turtles), even considering other heavy metals.

\section{Acknowledgements}

The authors are grateful to the Technology Laser Laboratory of IPN-CICATA Altamira to facilitate laser for LIBS characterization. Funds supported this work were from projects SIP20195614, SIP20196464, and SIP20201663 (México).

\section{Conflicts of Interest}

The authors declare no conflicts of interest regarding the publication of this paper.

\section{References}

[1] George, R., Martin, G.D., Nair, S.M. and Chandramohanakumar, N. (2013) Biomonitoring of Trace Metal Pollution Using the Bivalve Molluscs, Villorita cyprinoides, from the Cochin Backwaters. Environmental Monitoring and Assessment, 185 10317-10331. https://doi.org/10.1007/s10661-013-3334-9

[2] Marín-Mézquita, L., Baeza, L., Zapata-Pérez, O. and Gold-Bouchot, G. (1997) Trace Metals in the American Oyster, Crassostrea virginica, and Sediments from the Coastal Lagoons Mecoacan, Carmen and Machona, Tabasco, Mexico. Chemosphere, 34, 2437-2450. https://doi.org/10.1016/S0045-6535(97)00046-5

[3] Baqueiro-cárdenas, E.R., Borabe, L. and Goldaracena-islas, C.G. (2007) Mollusks and Pollution: A Review. Revista Mexicana de Biodiversidad, 78, 1-7.

[4] Valenzuela, B.A., Yánez, C.G. and Golusda, V.C. (2011) El ostión del norte chileno 
(Argopecten purpuratus), un alimento de alto valor nutricional. Revista chilena de nutrición, 38, 148-155. https://doi.org/10.4067/S0717-75182011000200005

[5] Finoto, L., Rondon, Y., Lima, C.A., Lima, S.M., da Cunha, L.H. and Lima-Junior, S.E. (2019) Use of Fish Scales in Environmental Monitoring by the Application of Laser-Induced Breakdown Spectroscopy (LIBS).Chemosphere, 228, 258-263. https://doi.org/10.1016/j.chemosphere.2019.04.070

[6] Ragi, A.S., Leena, P.P., Cheriyan, E. and Nair, S.M. (2017) Heavy Metal Concentrations in Some Gastropods and Bivalves Collected from the Fishing Zone of South India. Marine Pollution Bulletin, 118, 452-458.

https://doi.org/10.1016/j.marpolbul.2017.03.029

[7] Jonathan, M.P., Muñoz-Sevilla, N.P., Góngora-Gómez, A.M., Luna, R.G., Sujitha, S.B., Escobedo-Urías, D.C., Rodríguez-Espinosa, P.F. and Campos, L.E. (2017) Bioaccumulation of Trace Metals in Farmed Pacific Oysters Crassostrea gigas from SW Gulf of California Coast, Mexico. Chemosphere, 187, 311-319.

https://doi.org/10.1016/j.chemosphere.2017.08.098

[8] Câmara, V., Carqueija, F.A., Babosa, D.V. and Rodrigues, E. (2019) Direct determination of $\mathrm{Ca}, \mathrm{K}, \mathrm{Mg}, \mathrm{Na}, \mathrm{P}, \mathrm{S}, \mathrm{Fe}$ and $\mathrm{Zn}$ in Bivalve Mollusks by Wavelength Dispersive X-Ray Fluorescence (WDXRF) and Laser-Induced Breakdown Spectroscopy (LIBS). Food Chemistry, 273, 91-98. https://doi.org/10.1016/j.foodchem.2018.02.016

[9] Suami, R.B., Al Salah, D.M.M., Kabala, C.D., Otamonga, J.P., Mulaji, C.K., Mpiana, P.T. and Poté, J.W. (2019) Assessment of Metal Concentrations in Oysters and Shrimp from Atlantic Coast of the Democratic Republic of the Congo. Heliyon, 5, e03049. https://doi.org/10.1016/j.heliyon.2019.e03049

[10] Xu, L., Wang, Z., Zhao, J., Lin, M. and Xing, B (2020) Accumulation of Metal-Based Nanoparticles in Marine Bivalve Mollusks from Offshore Aquaculture as Detected by Single Particle ICP-MS. Environmental Pollution, 260, Article No. 114043. https://doi.org/10.1016/j.envpol.2020.114043

[11] Ferreira, C.P., Lima, D., Paiva, R., Vilke, J.M., Mattos, J.J., Almeida, E.A., Grott, S.C., Alves, T.C., Correa, J.N., Jorge, M.B., Uczay, M., Vogel, C.I.G., Gomes, C.H.A.M. and Bainy, A.C.D. (2019) Metal Bioaccumulation, Oxidative Stress and Antioxidant Responses in Oysters Crassostrea gasar Transplanted to an Estuary in Southern Brazil. Science of the Total Environment, 685, 332-344. https://doi.org/10.1016/j.scitotenv.2019.05.384

[12] Akpovo, C.A., Martinez, J.A., Lewis, D.E., Branch, J., Schroeder, A., Edington, M.D. and Johnson, L. (2013) Regional Discrimination of Oysters Using Laser-Induced Breakdown Spectroscopy. Analytical Methods, 5, 3956-3964. https://doi.org/10.1039/c3ay40491a

[13] Peng, J., Liu, F., Zhou, F., Song, K., Zhang, C., Ye, L. and He, Y. (2016) Challenging Applications for Multi-Element Analysis by Laser-Induced Breakdown Spectroscopy in Agriculture: A Review. TrAC Trends in Analytical Chemistry, 85, 260-272. https://doi.org/10.1016/j.trac.2016.08.015

[14] Cremers, D.A. and Radziemski, L.J. (2006) Handbook of Laser-Induced Breakdown Spectroscopy. John Wiley \& Sons Ltd., Chichester.

https://doi.org/10.1002/0470093013

[15] Chaudhary, K., Rizvi, S.Z.H. and Ali, J. (2016) Laser-Induced Plasma and Its Applications. In: Mieno, T., Ed., Plasma Science and Technology-Progress in Physical States and Chemical Reactions, IntechOpen, Japan. https://doi.org/10.5772/61784

[16] Singh, J.P. and Thakur, S.N. (2007) Laser-Induced Breakdown Spectroscopy. 1st 
Edition, Elsevier Science, Amsterdam.

[17] Hausmann, N., Siozos, P., Lemonis, A., Colonese, A.C., Robson, H.K. and Anglos, D. (2017) Elemental Mapping of Mg/Ca Intensity Ratios in Marine Mollusc Shells Using Laser-Induced Breakdown Spectroscopy. Journal of Analytical Atomic Spectrometry, 32, 1467-1472. https://doi.org/10.1039/C7JA00131B

[18] Ponce, L.V., Flores, T., Sosa-Saldaña, M., Alvira, F.C. and Bilmes, G.M. (2016) Laser-Induced Breakdown Spectroscopy Determination of Toxic Metals in Fresh Fish. Applied Optics, 55, 254-258. https://doi.org/10.1364/AO.55.000254

[19] Contreras, F. (1993) Ecosistemas Costeros Mexicanos. Universidad Autónoma Metropolitana, Unidad Iztapalapa, México.

[20] Vázquez-Sauceda, M.L., Aguirre-Guzmán, G., Sánchez-Martínez, J.G. and PérezCastañeda, R. (2011) Cadmium, Lead and Zinc Concentrations in Water, Sediment and Oyster (Crassostrea virginica) of San Andres Lagoon, Mexico. Bulletin of Environmental Contamination and Toxicology, 86, 410-414. https://doi.org/10.1007/s00128-011-0223-1

[21] Kramida, A., Olsen, K. and Ralchenko, Y. (2020) NIST LIBS Database. National Institute of Standards and Technology.

[22] Walne, P.R. and Mann, R. (1975) Growth and Biochemical Composition in Ostrea edulis and Crassostrea gigas. In: Barnes, H., Ed., 9th European Marine Biology Symposium, Aberdeen University Press, Scotland, 587-607.

[23] Yaroshchyk, P. and Eberhardt, J.E. (2014) Automatic Correction of Continuum Background in Laser-Induced Breakdown Spectroscopy Using a Model-Free Algorithm. Spectrochimica Acta Part B: Atomic Spectroscopy, 99, 138-149.

https://doi.org/10.1016/j.sab.2014.06.020

[24] Páez-Osuna, F., Zazueta-Padilla, H.M., Rodríguez-Higuera, A. and Osuna-López, J.I. (1991) Variación estacional de la composición química del ostión crassostrea corteziensis (Hertlein, 1951) en mazatlán (Sinaloa, México). Anales del Instituto de Ciencias del Mar y Limnología, 18, 199-206.

[25] Chávez-Villalba, J., Villelas-Ávila, R. and Cáceres-Martínez, C. (2007) Reproduction, Condition and Mortality of the Pacific Oyster Crassostrea gigas (Thunberg) in Sonora, México. Aquaculture Research, 38, 268-278. https://doi.org/10.1111/j.1365-2109.2007.01662.x

[26] Secretaría de Agricultura, Ganadería, Desarrollo Rural, Pesca y Alimentación (2016) Norma Oficial Mexicana NOM-015-SAG/PESC-2016 para regular el aprovechamiento de ostión (Crassostrea virginica) en los sistemas lagunarios estuarinos del Estado de Tabasco. Diario Oficial de la Federación, México.

[27] Boscolo, R., Cornello, M. and Giovanardi, O. (2003) Condition Index and Air Survival Time to Compare Three Kinds of Manila Clam Tapes philippinarum (Adams and Reeve) Farming Systems. Aquaculture International, 11, 243-254. https://doi.org/10.1023/A:1024888608791

[28] De la Guardia, M. and Garrigues, S. (2015) Handbook of Mineral Elements in Food. 1st Edition, John Wiley \& Sons Ltd., Chichester.

https://doi.org/10.1002/9781118654316 